\title{
Berenice detetive, de João Carlos Marinho ou um modo de matar familiares
}

\author{
Regina Chamlian \\ Universidade de São Paulo
}

uando, numa fatídica manhã do segundo semestre de 1986, quase ao fim do segundo capítulo de Berenice detetive, de João Carlos Marinho, tia Rosinha, a escritora de livros infantis, visita a escola onde estuda a turma do gordo, recebe das crianças seis maçãs, um vidro de perfume, livros do Frederico Morais e do Milan Kundera, uma cafeteira, rosas, entre outros presentes. Se ainda não leu este livro que ora comento, caro leitor, advirto-o que aqui revelarei quem é o assassino ou assassina e certos detalhes do crime nele ocorrido. Não me culpe depois por não avisar. Começo divulgando que tia Rosinha morre imediatamente após receber um dos presentes. Vejamos os seus últimos momentos:

Tia Rosinha respondeu mais duas perguntas, interrompeu-se, olhou para a mesa, pegou uma maçã, deu uma mordida, pegou uma caixa de perfume, abriu, tirou o frasco, passou o perfume na palma da mão, cheirou e disse:

- Hum, Fleurs d'Orlane, muito bom. Sou assim, meio distraída, só agora reparei nestes presentes e...

Não terminou a frase, tia Rosinha caiu no chão.

Edmundo impediu que a roda dos curiosos abafasse a respiração da doente, logo chegou o médico e disse que tia Rosinha estava morta. (MARINHO, 2006: 15)

Como descobriram Berenice e os demais detetives dessa narrativa, o que matou tia Rosinha foi uma maçã envenenada. Não terá sido a primeira vez, na história da literatura, que alguém é assassinado de forma tão elaborada: 
A maçã fora preparada com tanta habilidade, que só a parte que tinha a casca vermelha foi que ficou envenenada. Branca de Neve olhou para a maçã e seu aspecto era tão apetitoso, que fazia realmente dar água na boca. A menina não resistiu muito: enfiou a mão pela janela e pegou o pedaço de maçã. Mal levou o pedaço à boca, caiu morta. (GRIMM, 2000: 354)

O acerto da idéia de João Carlos Marinho ao escolher a 'arma' que mata a escritora, portanto, deve-se, de imediato, ao feliz cruzamento de duas tradições literárias, a do conto de fadas, como acabamos de ver, e a do gênero policial, prolífico no uso de venenos como modo de matar.

Além das ressonâncias intertextuais acima mencionadas, acrescente-se também o fato da maçã estar associada, por obra da mídia, ao lanche escolar das crianças e, conseqüentemente, à figura do professor, diversas vezes representado em filmes, livros e gibis com esta fruta sobre a mesa. Embora Tia Rosinha não seja professora, a cena se passa numa escola, e ela ocupa por certo tempo o lugar do professor. Por outro lado, não deixa de haver ironia e mesmo humor negro que num livro para crianças uma personagem escritora de livros infantis seja morta por uma maçã envenenada, que nos remete a um célebre conto de fadas.

A relação com Branca de Neve, no entanto, é mais importante num aspecto crucial de Berenice detetive, ao ecoar o tema deste conto de fada que aqui mais nos interessa: o assassinato de um filho.

Como sabemos, é a madrasta de Branca de Neve, a rainha invejosa, que mata a enteada com a maçã que envenenara. Nos contos de fada, porém, a alusão a madrastas e padrastos malvados seria mero disfarce dos pais 'verdadeiros'.

Rosinha acabou comendo a maçã envenenada por acaso, esta não lhe era dirigida. Quem devia comê-la era Carlos Eduardo, o filho de Alberto, doente de câncer. Foi Alberto que envenenou a maçã com cianureto. O móvel do crime que Alberto pretendia cometer, no entanto, não era inveja, mas compaixão: o que ele quis foi praticar em seu próprio filho a eutanásia, já que no estágio em que a doença deste se encontrava, as dores seriam a partir daquele momento inevitáveis.

Ainda assim, a referência intertextual explícita que a obra mantém com Branca de Neve parece-me marcar o gesto de Alberto com uma ambigüida- 
de que não se desfaz, mesmo não tendo ele conseguido levar a cabo o seu intento, mesmo estando seu filho em fase terminal. E, o tema do 'pai que dá ao filho uma maçã envenenada', que encontramos em "Branca de Neve" e no entrecho acima comentado, se repete ao longo de Berenice detetive.

A palavra 'veneno' nos remete de pronto ao sentido de “qualquer substância, preparada ou natural, que por sua atuação química é capaz de destruir ou perturbar as funções vitais de um organismo" (HOUAISS, 2001), mas abrange também as conotações simbólicas da expressão, relacionadas a tudo que mina as forças vitais, faz definhar, deprimir, adulterar, envergonhar ou corromper.

Alguns exemplos de como o tema do 'pai que dá ao filho uma maçã envenenada' é recorrente em Berenice detetive, além daquele central à narrativa, mais acima citado, seriam quando Pancho, o cachorro (muito querido) do gordo, quase morre intoxicado por ter engolido os psicotrópicos que o pai do gordo consome à larga e descuidadamente, ou em outras alusões indiretas, mais próximas da idéia de envenenamento simbólico da criança pelo adulto, como quando a mãe do gordo trama com outra mulher o namoro de seu filho com a filha daquela, para se livrar de Berenice, de quem não gosta, ou um dos garotos da escola mente para proteger as atividades criminosas do pai, ou um dos vilões pede para a filha esconder de todos um fato relevante para que possa exercer chantagem, tornando-a praticamente sua (constrangida) cúmplice.

Em todas essas passagens acima mencionadas de Berenice detetive, o doador do 'veneno' é o pai ou a mãe, o receptor, a criança, e o resultado, como sempre ocorre com a ingestão de venenos, sejam de efeito lento ou instantâneo, 'reais' ou simbólicos, é deletério.

\section{Referências Bibliográficas}

GRIMM, Jacob \& Wilhelm. Contos de fadas. Trad. David Jardim Júnior. Belo Horizonte: Itatiaia, 2000.

HOUAISS, Antonio. Dicionário Eletrônico Houaiss da Lingua Portuguesa, versão 1.0. Rio de Janeiro: Objetiva, 2001 - CD-ROM.

MARINHO, João Carlos. Berenice Detetive. São Paulo: Global, 2006. 